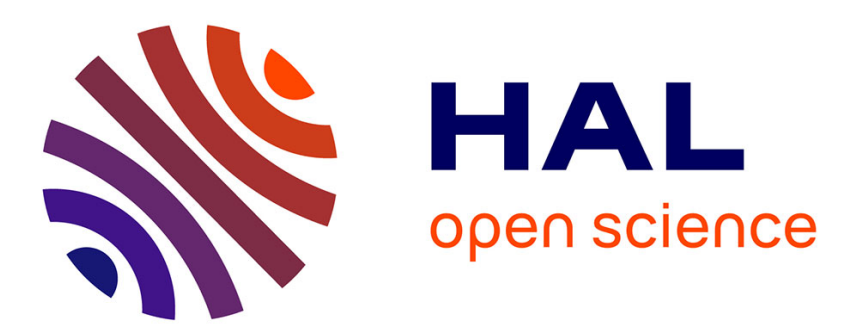

\title{
Qualification and comparison in Berber. The verb-noun distinction and its fluctuations \\ Catherine Taine-Cheikh
}

\section{To cite this version:}

Catherine Taine-Cheikh. Qualification and comparison in Berber. The verb-noun distinction and its fluctuations. STUF, 2014, Berber in typological perspective, 67 (1), pp.63-79. 10.1515/stuf-20140006 . halshs-01098723

\section{HAL Id: halshs-01098723 \\ https://shs.hal.science/halshs-01098723}

Submitted on 8 Jun 2018

HAL is a multi-disciplinary open access archive for the deposit and dissemination of scientific research documents, whether they are published or not. The documents may come from teaching and research institutions in France or abroad, or from public or private research centers.
L'archive ouverte pluridisciplinaire HAL, est destinée au dépôt et à la diffusion de documents scientifiques de niveau recherche, publiés ou non, émanant des établissements d'enseignement et de recherche français ou étrangers, des laboratoires publics ou privés. 


\title{
Qualification and comparison in Berber The verb-noun distinction and its fluctuations
}

\begin{abstract}
The world's languages generally distinguish between nouns and verbs. However, many do not have a specific class of adjectives with its own significantly different grammatical properties to set it apart from nouns and verbs. This is true of Berber which, in this respect, differs from Arabic. That being said, if one looks at the details, there is wide variety across Berber languages. Most have both "verbal" adjectives and "nominal" adjectives, with more or less marked secondary properties. Some have a small adjective class for describing certain core properties. Historically, these could reflect an earlier phase of Berber.
\end{abstract}

Keywords: Berber, qualification, adjective, syntactic categories, predicative $v s$ attributive function

\section{Introduction $^{1}$}

One of the roles of all grammars is to identify a language's lexical classes. To do so, it is often crucial to determine whether the language has a specific adjectival class (see VOGEL \& COMRIE, 2000). This is because although qualification and comparison are often expressed by adjectival lexemes, the latter are not necessarily distinct, from a functional perspective, from other lexemes (more particularly verbal and nominal lexemes), or, when there is a distinction, it is often hazy. Thus DIXON identifies five major language types (1999: 4) depending on how their grammars integrate adjectives. Based on BASSET's (1952) study, he states that the Berber languages belong to type (3), a rare type where:

"There is an open class of adjectives which has grammatical properties that are effectively the sum of those of noun and of verb - when an adjective occurs in a noun phrase it can take the same inflections as a noun, and when it occurs as head of a predicate it can inflect in the same way as a verb".

Among Berber specialists the question of whether adjectives constitute a specific syntactic class is still being debated. Some authors, e.g. BenTOLILA (1981),

The following abbreviations are used: ADJ 'adjectival; adjective', AOR 'Aorist', AS 'Annexation State', cj. 'conjugation', FS 'Free State', F 'feminine', GEN 'genitive preposition', IPFV 'Imperfective', M 'masculine', PFV 'Perfective', PL 'plural', PROX 'proximal', PTCP 'participial suffix', SG 'singular'. The symbol ${ }^{\wedge}$ indicates that an assimilation has not been noted. All Mauritanian Zenaga data are from the author's fieldwork (see in particular TAINE-CHEIKH 2008). 
consider that northern Berber does not have qualifying adjectives. Others such as CHAKER (1995) believe that in at least some Berber varieties, e.g. Kabyle, adjectives constitute a subclass within the noun class.

My goal here is to examine how the various units which translate the idea of qualification or assessment function. Beginning with the verb/noun distinction, I will explore the hypothesis of a possible continuum between these two extremes. I will also consider the hypothesis set forth by GIVÓN (1984: 52) whereby he posits that prototypical adjectives are "intermediate states" between verbs and nouns from the perspective of temporal stability (the Time Stability Hypothesis). It would indeed be interesting to establish whether semantic and grammatical hierarchies coincide, and whether, in both, adjectives show a tendency to occupy an intermediate position between the two extremes of both.

(1) a.

increasing time-stability

\begin{tabular}{|c|c|c|}
\hline EVENTS/ACTIONS & & PROPERTIES $^{2}$ \\
\hline
\end{tabular}

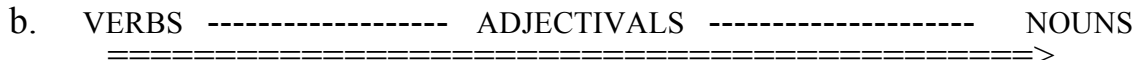

decreasing verbality / increasing nominality

Below I reproduce the diagrams of WETZER (1996: 52), however I will study not only the predicative function of "adjectives" (the above author's field of study) but also their attributive functions.

\section{Verbal extreme}

\subsection{Purely semantic specificities}

In all Berber languages there are lexemes which behave like verbs in morphosyntactic terms, but which also express physical or moral characteristics more in line with the idea of qualification. BASSET (1929) provides the following examples: karam 'be cold' and abzag 'be wet' in Semlal Tashelhiyt; uray 'be yellow' in the Rif (warray for the Seghrouchen); rzay 'be bitter' in Metmata and the Aurès, gužal 'be an orphan' and taz 'be close' in Kabylia; iyar 'be dry', uzzaf 'be black', lamzaggan 'be lukewarm' and muzzu 'be roomy' in Ahaggar; aden/aten 'be ill' almost everywhere.

The values of the system's two basic forms - Perfective and Imperfective - do

2 As Creissels (2006: 200) notes, nouns, adjectives and verbs are all logically capable of expressing properties, but lexemes which express scalable and relatively general physical characteristics such as big/little, fat/thin, long/short, etc. "tendent à fonctionner comme prototype de classes morphosyntaxiques d'adjectifs, de la même façon que les classes de noms et de verbes s'organisent autour de prototypes mettant en jeu respectivement les notions de personne humaine et d'événement" ("tend to function as the prototype for the morphosyntactic class of adjectives, just as noun and verb classes are organized around prototypes referring respectively to the notions of person and event"). 
not appear to fully coincide in all Berber languages, but "quality" verbs often have their own particularities, especially in the case of pure statives: "l'inaccompli exclut l'état"” ("the imperfective excludes states") (GALAND 1980: 352). Thus in Zenaga, the statives meaning 'be beautiful' (iymundur) and 'be thin' (äymuđ̆) are essentially used in the Perfective with timeless continuous meaning: yäymandar 'he is beautiful' and yiymat 'he is thin'. On the contrary, the statives/inchoatives meaning 'be/become famished' (umpinugziy) and 'be/become stable' (ärgəg) can be used in both forms, and inchoative meaning is only conveyed in the Imperfective (with present or future meaning): yargäg 'he is stable/has become stable', yittargug 'he is becoming/will become stable'.

The "quality" verbs under consideration here, like most verbal lexemes, have a single affixal system for all conjugation paradigms (except in the imperative): ${ }^{3}$ person markers are suffixed (1SG, 3PL), prefixed (3SG.M, 3SG.F, 1PL) or both (2SG, $2 \mathrm{PL})$. In the preceding examples, initial $y$-marks the 3SG.M (y-argäg).

"Quality" verbs, like all verbs, are mainly used in predicate function. Any verb form bearing a person marker constitutes a full sentence. The marker agrees in gender and number with the lexeme it represents, whether present or not in the clause. ${ }^{4}$ Thus in Zenaga:

(2)

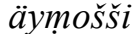
knife
a) $y$-iyā $h$
3SG.M-be.sharp.PFV

a) 'the knife is sharp'.
äymošš $i$
knife
a) $y$-uđạr 3SG.M-fall.PFV.

a) 'the knife fell' b) wär y-iȳh NEG 3SG.M-be.sharp.NEG.PFV

b) 'the knife is not sharp'.

b) wär $y$-uđưr NEG 3SG.M-fall.NEG.PFV

b) 'the knife didn't fall'.

Whether the verb be a "quality" verb (yiyāh) or an action verb (yuđara), there is no formal difference between examples (2) and (3). The same is true of secondary predicates, for example in relative clauses where the person marker on the verb refers to the antecedent (and in which case the relative clause cannot contain an explicit lexical subject). These relatives (see GALAND, same volume, section 3.5) are recognizable in that they bear a "participial" verbal suffix, generally containing a nasal consonant. ${ }^{5}$ Thus in Zenaga (SG - än, PL -in):

$$
\begin{array}{ll}
\text { uzzar-ag } & \text { t-arbaat } \\
\text { see.PFV-1SG } & \text { F-girl.SG } \\
\text { 'I saw a/the girl }
\end{array}
$$
a) t-uđ̛̣ur-än 3SG.F-run.PFV-PTCP
a) (who) fell'

b) t-äymändar-än 3SG.F-be.beautiful.PFV-PTC

b) (who) is beautiful'

The so-called participial form of the verb is identical for all verbs in a given language, however some eastern varieties such as Nafusi and Siwi do not have a

3 Only a few eastern varieties such as Ghadamsi show specificities in the singular Future (KOSSMANN 2000a).

4 If postposed on the verb, the "subject" lexeme is in the annexation state (AS), except in the case of Berber varieties such as Zenaga which do not distinguish between state types.

5 One also finds dental consonants, e.g. $-t$ in the 3SG.F, in Tuareg. Alongside Galand (2006: 60), I believe this $-t$ to be secondary, and that $-n$ was formerly the only suffix. 
"participial" suffix (LAOUST 1931: 55). ${ }^{6}$ Moreover, in some varieties, the "participial" relatives are used only if the antecedent is definite; such is the case in eastern Riffian (KOSSMANN 2000b: 156).

\subsection{Specific patterns}

Beyond the case of the Imperfective, which usually requires the prefixation of $t$ or gemination of one root consonant, the various verbal aspect-tense or aspectmood paradigms (TAM) - Aorist vs. Perfective, affirmative Perfective vs. negative, etc. - are mostly distinguished by changes in the vowel pattern. Moreover, these patterns vary from dialect to dialect, depending on each variety's verbal sub-classes. While the pattern in the (affirmative) Perfective is often of the type $(i / u / \partial)-a$, one notes that it is often of the type $(\ddot{a})-i / u / \partial$ for "quality" verbs. In southern varieties, vowel alternations are particularly striking.

For Tahaggart, PRASSE (1973-74: VII, 145) establishes that "[s]émantiquement, les verbes de la cj. II étaient des verbes inintentionnels (signifiant surtout des fonctions sensorielles et mentales) et des verbes de qualité passagère" ("[s]emantically, verbs in cj. II were unintentional verbs (referring mostly to sensory and mental functions) and verbs denoting passing qualities"), and that there is a ( \pm intentional) semantic opposition between:
(5) Cj. I 'choose'
AOR ifran
PFV ifrän NEG.PFV ifrin
$\mathrm{Cj}$. II 'be distinguished' AOR yufran
PFV yäfrun NEG.PFV yäfrun

One finds a comparable distinction in Zenaga. The patterns are exactly inversed in Perfectives: "non- $a$ "-“ $a$ " vs. " $a$ "-"non- $a$ " (COHEN \& TAINE-CHEIKH 2000):
(6) $\mathrm{Cj} . \mathrm{I}$ 'fall'
$\mathrm{Cj}$. II 'dry out'

$$
\begin{aligned}
& \text { AOR yađ̛̣r PFV yuđ̛̣ar NEG.PFV yuđ̛̣r } \\
& \text { AOR } y u^{\text {? } m u m ~ P F V ~ y a ̈ ' m ̣ u m ~ N E G . P F V ~ y u ' m ̣ u m ~}
\end{aligned}
$$

In this language, verbs in cj. II are mostly inchoatives. Some of the latter form pairs with related stative verbs having the constant vowel pattern "non- $a$ "-" $a$ ". Whence the following distinction in the NEG.PFV (TAINE-CHEIKH 2009):
(7) a) 'dry out':
NEG.PFV
$w a ̈ r^{\wedge} y u^{\top} m \underline{u m} \quad$ 'it has not dried out'
$w \ddot{a} r^{\wedge} y a^{2} m u m$ 'it is not dry'
b) 'be dry':
NEG.PFV

The situation in Siwa, with very rare "quality" verbs of Berber origin (LAOUST op. cit.: 62-65) is inverse to that of the southern varieties?

\section{3. "Quality" verbs with specific conjugations}

In several Berber varieties, stative verbs expressing adjectival type properties have an irregular Perfective paradigm, with its own specific pattern and conjugation. In Tahaggart, verbs in this sub-class (cj. IV in PRASSE 1973-74: VII, 182 ) in this case refer to permanent qualities rather than transient ones:

\footnotetext{
Also note in Nafusi (BEGUINOT 1933: 119): aterrâs yéza'ám 'a good person'.

Here I leave aside the question of the suffix $-a$ the use and the value of which are currently a matter of discussion.
} 
$\begin{array}{lllllll}\text { (8) Cj. IV 'be tall' } & \text { AOR imyar } & \text { IMPFV itimyar } & \text { PFV } & \text { mäqqür } \\ \text { 'be soft' } & \text { AOR ilmad } & \text { IMPFV itilmad } & \text { PFV } & \text { lammid }\end{array}$

In Tuareg, the Perfective conjugation has become almost completely regular, with the exception of the absence of $i$ - in the 3SG.M. ${ }^{8}$ Kabyle and Ghadamsi on the contrary have retained the simplified conjugation, with a single form in the plural. Thus the Perfective of amtit 'be small' in Ghadamsi (LANFRY 1968: 285):

(9) $1 \mathrm{SG}$ mettīt-e $\quad$ 2SG mettīt-at $3 \mathrm{SG} . \mathrm{M}$ mettīt $3 \mathrm{SG} . \mathrm{F}$ mettit-et PL mettit-it

These forms are those used in predicative function, with or without negation $a k$ being the usual negation of the Perfective in Ghadamsi (op. cit.: 362):
a) $t i^{\top} e t t=u$
mellal-et
'this goat is white'
b) $w a ̣ l l i=y i$ ak mellūl-it
'these goats are not white'

When serving as predicate in "participial" relatives, these Perfectives take the same suffixes as the other verb forms. However, the prefixes $i$ - and $t$ - in the $3 \mathrm{SG}$ are generally omitted. ${ }^{9}$ Thus in Ghadamsi (ibid.):

(11) wạḡgid zağrut-ən 'a big (long) man'

In Tashelhit, where the perfective paradigm of the "quality" verb has been entirely regularized, one still finds the older prefixless participle, whereas it has completely disappeared from central Morocco (Galand 2010a: 238).

\subsection{Syntactic specificities of the comparative}

Comparisons may be effected using verbal lexemes such as ägur or $u f$ 'be superior to, exceed' (in Shilha, ati 'outnumber' and af 'be better', EL MOUNTASSIR 1995: 100). Zenaga has other verbs of the same type, with much more precise semantics (TAINE-CHEIKH 2012: 274-9): yizzäh 'he is better than', yuđrä 'he is more beautiful than', yäma'rlyuyäg 'he is older than', yamașk 'he is younger than'.

With such verbs, manner modifiers are often expressed via a preposition ( $g$ 'in', $s$ 'with'...). Some languages however, such as Zenaga and Tuareg, show a direct construction, also found in Arabic, which appears to be archaic. ${ }^{10}$ Thus in Zenaga:

(12) $t=u đ r \ddot{a}$

$$
a \dot{g} m a=n=\check{s} \quad \text { əðəm }
$$

3SG.F=be.more.beautiful.than.PFV brother.SG.M $=$ of $=$ PRON.3SG face.M.SG

'her face is more beautiful than her brother's' (lit. 'she is more beautiful than her brother in her face/as far as the face is concerned').

8 Moreover, presence of the prefix $t$ - in the 2 nd person is optional.

9 This prefixless participial form has extended to all verbs in Awdjilah (PRASSE 1989: 1054).

10 Other languages of the world, such as Igbo, have the same construction (CROOKSTON 1999:79). For Arabic (and more especially Ḥassāniyya), see TAINE-CHEIKH (1984: 296- 299). 


\section{Nominal extreme}

\subsection{Purely semantic specificities}

In Berber there are numerous nominal forms which express physical or moral qualities, but which show no morphological or syntactic characteristics to set them apart from other nominals. In Zenaga, such is the case of ägmär which means 'tall' (as well as 'young adolescent') and of numerous nominal forms with a nasal prefix. The fact that habitual meaning is inherent in these forms in $n-/ m$ - has given rise to "adjectival" morphemes which correspond to more or less transient properties (änähtzf 'mistrustful', amugniš 'having a fighting spirit', änäffuđ '(constantly) thirsty'...) and "substantival" lexemes referring, among others, to professions and

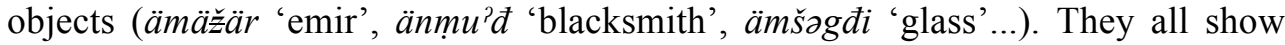
similar agreement in gender and number, taking the same affixes: SG.M $a-$, SG.F $t a-t$, PL.M $\partial-\ddot{a} n$, PL.F $t \partial-\partial n$.

Like their Tuareg equivalents, ${ }^{11} \ddot{a g m a ̈ r}$ and Zenaga forms with a nasal prefix show the same syntactic behavior as nouns.

To serve as predicates, like other nouns (13a, 14a), they require the presence of an auxiliary: either the deictic äd (13), or the verb ägi 'become' which, in combination with the negation marker wär, gives rise to the contracted form $w \ddot{a}=y g i(14)$.

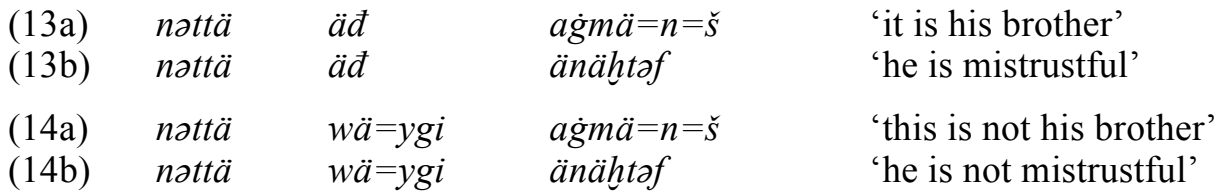

To modify a noun, a genitive construction is used containing the preposition $\partial n$ $\left(\mathrm{N}_{1}\right.$ an $\left.\mathrm{N}_{2}\right)$. The only particularity to be noted in (15b), as compared to ordinary noun modifiers (15a), is that $\mathrm{N}_{2}$ agrees in gender and number with $\mathrm{N}_{1}$. However this is similar to superlative constructions (16) where there is agreement in gender - and in number with ägmär in (16a) - between $\mathrm{N}_{1}$ and $\mathrm{N}_{2}$.

\begin{tabular}{|c|c|c|c|c|}
\hline (15a) & $t-n i \check{s} t^{y} \partial m-t$ & $\partial n$ & $\ddot{a} m \ddot{a} z \ddot{a} r$ & '(the) emir's wife' \\
\hline $15 b$ & $t-n i \check{s} t^{y} \partial m-t$ & $\partial n$ & $t-\ddot{a} n a ̈ h t \partial f-t$ & '(a/the) mistrustful woman' \\
\hline 5 & $\begin{array}{l}t \text {-ägmär } t \\
w a^{2} r \quad \partial n\end{array}$ & $\begin{array}{l}\partial n \\
i r a ̈ n\end{array}$ & $\begin{array}{l}t-m ə k s ̌ a n-t \\
\text { (lit. 'lion among lions') }\end{array}$ & $\begin{array}{l}\text { 'the greatest enemy' } \\
\text { "the strongest of lions, }\end{array}$ \\
\hline
\end{tabular}

The structure $\mathrm{N}_{1} n \mathrm{~N}_{2}$ is highly productive in Berber. GALAND ([1969] 2002: 204-5) notes a variety of examples in several languages. The following is taken from Foucauld (1951-52: I, 33). It is comparable to (15) but has a proper noun as $\mathrm{N}_{1}$ :

11 In Tahaggart, forms in $n$ - $/ m$ - refer to humans or animals having a specific quality: amyar 'tall man', ănäywal 'duck-footed man or animal'. These are true nouns, even though PRASSE (1973-74: IV, 97) calls them "verbal adjectives".

12 There is no difference between relative and absolute superlatives. Thus (16a) could be translated as 'a very great enemy' and (16b) as 'a very strong lion'. 
'Mimi of the mad woman, Mimi's mad woman'

\subsection{Some morphological specificities}

Chaker (1995: 25-28) lists the various adjective patterns found in the northern Berber dialects and concludes: "adjectives are often recognizable by their form". $a C C a c, a C v C a C$ and $a C C C v C$ are patterns found in both nouns and adjectives. But $u C C i C, a M / N---u, i M i C C i C$ and above all (a)CCan, (a)CC:Can, (a)CvCan are only found in adjectives. Chaker suggests considering the suffix - an (present in aberkan 'black', aquran 'dry', azayan 'heavy'...) as an adjective suffix. ${ }^{13}$

In Kabyle, the patterns $u C C i C$ and $i M i C C i C$ often convey "imperfection of the quality", whence the following distinctions: amllal 'white' vs. umlil 'whitish'; aberkan 'black' vs. imibrik 'blackish'. The same semantic shades are expressed elsewhere through different means. In Figuig, by using the prefix ca: camlal 'whitish' (KOSSMANN 1997: 120). In Tamazight, by the affix $h r$ - (GALAND 2010b: 54): ahrmLal 'whitish'.

Such (alongside the relational suffix $-i / y$ and constructions with $b u$ 'that of' or war "without') are the main indicators whereby an adjective (or an "adjectival" noun) can be recognized by its form.

\subsection{Some syntactic specificities}

The predicative uses of "adjectival" nouns have few specificities as compared to other nouns. Generally speaking, predicative auxiliaries are used, and adjectival predicate negation is the same as for nominal predicates.

In Shilha (18), it is the verb $g$ 'do'. In many northern varieties, namely in Kabyle (19), predication is mediated by $d-$ a deictic which is present even when the clause is negated.

(18) a) iga argaz 'it is (a) man'

(19) a) $d$ argaz 'it is (a) man'

b) iga umlil 'he/it is white'

b) d amllal 'he/it is white'

In Nafusi (BEGUINOT 1931: 118), there is no predication auxiliary (as for nouns). However, the subject is often modified by a demonstrative (here $\bar{u} h$ ):

$$
\text { bušil üh ameškân 'this guy is small' }
$$

The same is true in Siwi (LAOUST ibid.), except that the negation marker used $(l a)$ is that of verbal predicates (noun predicates take qačči). This is one of the rare elements which distinguish between adjective and noun predicates.

The differences are much greater however in the attributive uses of "adjectival" nouns. In parallel to the rather limited use of the genitive construction $\left(\mathrm{N}_{1} n \mathrm{~N}_{2}\right)$, one very often finds direct constructions, without $n$.

'Adjectival' determination is distinct from genitive constructions without $n$ on several points. On one hand (for all varieties which distinguish between states), one

13 He further notes that adjectives in -an are almost always formed on a stative verb. 
finds $\mathrm{N}_{2}$ in a free (or absolute) state. ${ }^{14}$ Whence the distinction highlighted by CHAKER (op. cit.: 24) between the attributive adjective in (21a) and the substantivized adjective serving as noun modifier, in (21b):

$\begin{array}{llll}\text { (21a) afus aberkan (FS) } & \text { 'the/a black hand' } \\ \text { (21b) afus } & \text { uberkan (AS) }\end{array}$

On the other hand, one notes agreement in gender and number between $\mathrm{N}_{1}$ and $\mathrm{N}_{2}$.

Although agreement in gender and number has become generalized in the varieties using this construction, at times one finds differences between masculine and feminine - but it might be misinterpretation. ${ }^{15}$

Other varieties also show some alternation (presence vs. absence of $d$ ), but it depends on whether $\mathrm{N}_{1}$ is modified or not. In Ouargla, according to BIARNAY (1908: 186), a direct construction is used when $\mathrm{N}_{1}$ is determined (aidi ou amellal 'my white dog'), but $d$ precedes the adjectival noun if $\mathrm{N}_{1}$ is entirely undetermined:

\begin{tabular}{lllll} 
iioui & $d$ & \multicolumn{1}{c}{ adyay } & $\boldsymbol{d}$ & aziouar \\
bring.PFV.3sG.M & PROX & rock.SG.M & COP & big.SG.M \\
'he brought a big rock' (lit. 'he brought (a) rock (it) is big')
\end{tabular}

In Djerba, $d$ (with a specific accentuation) has also come to mark indefiniteness according to VYCICHL (2005: 140-1): ${ }^{16}$
a) without COP:
áfrux
ámeqran
'the big boy'
b) with COP:
afrux
d ámeškan
'a little boy'

In Awdjilah (PARADISI 1960: 158), definiteness is also expressed by direct constructions. Here however speakers have the choice between an "adjectival" noun (mlîl 'white', ameskún 'small', amoqqarân 'tall') and an "adjectival" verb: mellél '(be) white', meššék '(be) small', móqqar '(be) tall' ${ }^{17}$ The same situation obtains in Nafusi (BEGUINOT op. cit.: 118):
a) "adjectival" noun:
bušil ameškân
'the little boy'
b) "verbal" adjective:
bušil meššék
'a little boy'.

4 On the free/annexed state opposition, see METTOUCHI, this volume.

15 Thus in the Tunisian Sened dialect, the copula $d$ appears after ergäz (masculine noun) but not after the feminine noun tamettut (Provotelle 1911: 92):
(22) ergäz
d amoqqrar
t-amettu-t
t-ausser- $t$ äm netta
'An old man had a wife who was as old as he'

The distinction ( $d$ vs. $\varnothing$ ) reappears in predicative function (ibid.: 44).

16 The same is true in eastern Riffian (Kossmann 2000: 155). In Siwi on the other hand it is an $n$ which at times appears before the adjectival noun. VyCichl (op. cit.: 213) interprets this $n$ as an indefinite marker whereas SoUAG (2010: 151-2) instead considers it a generic marker.

17 The adjectives vúrek 'largo' and fešûš 'leggero' are nonetheless used with both definite and indefinite meaning (PARADISI op. cit.: 168). 


\section{The noun-verb continuum}

\subsection{Adjectives which can (more or less) inflect}

In section 1.3. we saw that the "quality" verbs examined only showed specific behavior in the Perfective, where inflection is suffixed and the meaning is purely static. This is particularly true of "qualitative" verbs in Kabyle, in Ghadamsi and, to a lesser extent (due to the presence of certain prefixes) in Tuareg.

In other varieties however "quality" verbs are stative verbs showing defective inflection (they only inflect in the Perfective). Such is the case in Awdjilah where the verb meššék has only five distinct forms (PARADISI op. cit: 171):

(26) meškâh 'I am small'; meškât 'you are small'; meššék 'he is small'; meškét 'she is small'; mešš̌lkit 'we/you/they are small',

It is also the case in Nafusi and Zenaga, except that in the latter variety there is a distinction between the Perfective form of "quality" processive verbs and stative verbs, which have suffixal inflections - which is why for Zenaga I choose to speak of "inflected adjectives" (TAINE-CHEIKH 2003). Thus in Zenaga:

\begin{tabular}{|c|c|c|c|c|}
\hline 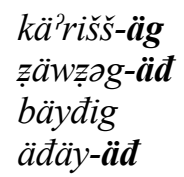 & $\begin{array}{l}\text { 'I am active' } \\
\text { 'you are deaf' } \\
\text { '(he/it is) green' } \\
\text { '(she is) brown' }\end{array}$ & $\begin{array}{l}\text { vs. } \\
\text { vs. } \\
\text { vs. } \\
\text { vs. }\end{array}$ & 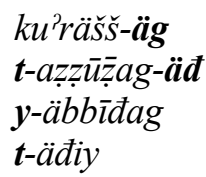 & $\begin{array}{l}\text { 'I became active' } \\
\text { 'you became deaf' } \\
\text { 'he/it became green' } \\
\text { 'she became brown' }\end{array}$ \\
\hline
\end{tabular}

In Zenaga adjectives constitute quite an important category. They generally have the pattern $\mathrm{CaCCi} / u / \partial C$ (or a variant thereof such as $C a C \bar{l} / \bar{u} C: k \ddot{a} y \bar{y} y$ 'short') ${ }^{19}$ and differ from both verbs and nouns.

Morphologically speaking, they behave inflect like verbs - but they inflect only through suffixation and mostly in the $1 \mathrm{SG}$ and $2 \mathrm{SG}$. In impersonal forms (3SG and 3PL), they differ from nouns i) in the absence of both the initial vowel and the prefix, and ii) in their specific paradigm of suffixed markers. Compare, in Zenaga:
a) “verbal” ADJ: '(be) green'
$\begin{array}{ll}\text { SG.M } & \text { bäyđig } \\ \text { PL.M } & \text { bäyđig-əd }\end{array}$
SG.F bäyđig-äd
PL.F bäyđig-ad
b) ADJ noun: 'mistrustful'
$\begin{array}{ll}\text { SG.M } & \ddot{a} n a ̈ h t \partial f \\ \text { PL.M } & \text { onähtaf-än }\end{array}$
SG.F
$\boldsymbol{t}$-änähtəf-t
PL.M onähtaf-än PL.F t-anähtวf-ən ${ }^{20}$

Syntactically speaking, they essentially behave like verbs in predicative function:

18 The situation in Nafusi is similar, but the adjective does not take a person marker in the 1SG and 2SG.

19 The pattern $C v C C v C$ is widespread in the other varieties. This means that in Ghadamsi it corresponds to the pattern often found in the Perfective of "quality" verbs (LANFRY 1968: 286):

(28) madri '(be) small'; semmad '(be) cold'; settef '(be) black'; zaggay '(be) red'; etc.

20 In some western Riffian varieties, the "verbal" adjective and the adjectival noun coexist and are both used — with or without $\underline{d}$ — after ag $u l$ 'become' (LAFKIOUI 2007: 165):

(30) a) "verbal" ADJ: ag்l-eg meqqur (M)/meqqur-et (F) 'I (M/F) became big'

b) ADJ noun:- a agul-eg $\underline{d}$ ameqran $(\mathrm{M}) / \underline{t}$-ameqran- $\underline{t}(\mathrm{~F})$ ' $\mathrm{I}(\mathrm{M} / \mathrm{F})$ became big'.

Moreover, there exists also the stative verb's Perfective (which is normally conjugated): $i$-meqqur 'he/it is big'. 
without the copula $\ddot{a} d$ and sharing the same verbal negation marker wär (cf. (2)(3)). Compare the behavior of the adjective in (31) to that of the nouns ((13)-(14)):
(31) Zenaga
a) nattä
b) nattä
mänag
'it is comfortable'
'it is not comfortable'

When used as a modifier (attributive), it is in the "participial" form (like the verb in (4), with no prefix however in the SG). Compare the behavior of the Zenaga adjective in (32b) to that of the adjectival noun in (15b):

\begin{tabular}{|c|c|c|c|c|c|}
\hline Zenaga & $\begin{array}{l}\text { a) } \\
\text { b) } \\
\text { c) } \\
\text { d) }\end{array}$ & $\begin{array}{l}\text { SG.M } \\
\text { SG.F } \\
\text { PL.M } \\
\text { PL.F }\end{array}$ & $\begin{array}{l}\text { äräbih } \\
\text { tarbađ̆đ } \\
\ddot{a r a ̈ b} \bar{a} n \\
\text { träbīn }\end{array}$ & 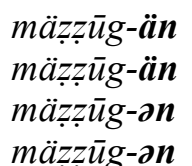 & $\begin{array}{l}\text { '(a/the) little boy' } \\
\text { '(a/the) little girl' } \\
\text { '(the) little boys' } \\
\text { '(the) little girls'. }\end{array}$ \\
\hline
\end{tabular}

In Nafusi on the contrary, because the form bears no "participial" suffix this means that, like for the verb (cf. note 6), there is very little to distinguish between the adjective's two functions:
(33) Nafusi
a) nìt mellél
b) aterrás mellél
'it/he is white'
(egli è bianco)
'a white man'
(un uomo bianco $)^{21}$

\subsection{Adjectival comparatives and superlatives}

Comparisons are generally expressed through modifiers, with the predicative core (whether verbal or nominal) remaining unchanged. There are nonetheless two specific constructions which we will examine here.

Several Berber languages use comparative forms borrowed from Arabic. These were originally adjectives having the pattern $a C C a C$ in the M.SG, which became invariable in the Arabic dialects. In Berber, these forms appear to be used without predication auxiliaries, even in those dialects which normally require one (cf. PROVOTELLE op. cit.: 44-5). Furthermore, Siwi revisited the Arabic comparative system by attributing a different pattern to it $(C C \curvearrowright C)$ and extending it to Berber lexemes (SOUAG 2010: 158):
(34) Siwi
$\begin{array}{llll}\text { a) aqdim 'old' } & > & \text { qdam } & \text { 'older' } \\ \text { b) agzal 'short' }> & \text { gzal } & \text { 'shorter' }\end{array}$
$(<$ Arabic $)$
$(<$ Berber $)$

The second specific construction concerns two superlative forms meaning '(very) bad, (the) worst' and '(very) good, (the) best'. Thus in Zenaga:

\begin{tabular}{|c|c|c|c|}
\hline$(35 a)$ & M.SG & $\ddot{a} g m \ddot{a}^{\wedge} m \overline{i n}$ & 'best individual' \\
\hline & M.PL & ogmä $m \bar{a} n$ & 'best individuals' \\
\hline & F.SG & t-ägär tnäwđad & ‘worst year’ \\
\hline & F.PL & t-gär tnūđän & 'worst years'. \\
\hline
\end{tabular}

One finds traces of the second in several Berber languages where they are (almost) always distinguished from nouns and verbs - both morphologically and

21 The same is true for nouns, because there is no copula (BEGUINOT op. cit.: 118). 
syntactically (GALAND 2010a: 153; TAINE-CHEIKH 2012: 273-7). The evaluative is in head position and is not followed by $n$ (contrary to nouns). When it is not invariable, it agrees in gender and number with the noun it modifies (however variation is irregular and only affects the initial segment). ${ }^{22}$

\section{Conclusion}

DIXON was right to highlight the substantial crosslinguistic variations in the syntactic categories called upon to express adjectives. Berber languages however do not all belong to a single type, and one notes a tendency across all of the languages (with exceptions such as Tuareg and Ghadamsi) to make use of several different syntactic devices (see Table 1). Generally speaking, some "adjectives" behave like verbs and others like nouns - either completely, or partially (which explains the existence of specific sub-classes). One also finds classes made up solely of adjectives. ${ }^{23}$ This is particularly clear in Zenaga and Awdjilah (spoken geographically far from each other), noting however that the data in these two varieties show major similarities with some "quality" verbs (having a specific Perfective paradigm) found in other varieties.

Table 1: ZEN 'Zenaga', SHL 'Shilha', KAB 'Kabyle', TRG 'Tuareg', GHD 'Ghadamsi', AWJ 'Awdjili', NAF 'Nafusi', SIW 'Siwi'

\begin{tabular}{|c|c|c|c|c|c|c|c|c|c|c|}
\hline & \multirow{4}{*}{$\begin{array}{c}\text { ZEN } \\
+ \\
+\end{array}$} & \multirow{4}{*}{$\begin{array}{c}\text { SHL } \\
+ \\
(+)\end{array}$} & \multirow{4}{*}{$\begin{array}{c}\text { KAB } \\
+ \\
(+)\end{array}$} & \multirow{4}{*}{$\begin{array}{c}\text { TRG } \\
+ \\
+\end{array}$} & \multirow{3}{*}{$\begin{array}{c}\text { GHD } \\
+\end{array}$} & \multirow{3}{*}{$\frac{\mathrm{AWJ}}{+}$} & \multirow{3}{*}{$\begin{array}{c}\text { NAF } \\
+\end{array}$} & \multirow{3}{*}{$\begin{array}{c}\text { SIW } \\
(+)\end{array}$} \\
\hline & & & & & & & & & & \\
\hline \multirow{4}{*}{ VERB } & 1 & ADJ verb & & & & & & & & \\
\hline & A & spec. pattern & & & & & + & - & - & \\
\hline & & PFV without prefixes & & - & + & $(+)$ & + & & & \\
\hline & B & PTCP without prefixe(s) & & $(+)$ & + & + & + & & {$[\varnothing]$} & [Ø] \\
\hline \multirow{3}{*}{\multicolumn{2}{|c|}{ NOUN }} & ADJ noun & + & + & + & - & - & + & + & + \\
\hline & & spec. syntax & - & + & + & & & + & + & NEG \\
\hline & & attributive / predicate & $\neq$ & $\neq$ & $\neq$ & & & $\neq$ & $=$ & $=$ \\
\hline \multirow{4}{*}{ [ADJ] } & & spec. pattern & + & & + & + & + & + & + & \\
\hline & & cj. without prefixes & + & & + & $(+)$ & + & + & + & \\
\hline & & spec. 3F.SG \& PL suff. & + & & + & $(+)$ & + & + & + & \\
\hline & & comparative/superlative & + & $(+)$ & $(+)$ & + & & & & + \\
\hline
\end{tabular}

The "intermediate states" are attested in the ancient Berber language. I believe that the adjective category (recognizable by its pattern and its specific gender and number markers) must have existed in Proto-Berber. ${ }^{24}$ There would have been very few adjectives, and they would have expressed properties such as size, color and perhaps certain physical defects (similar to the af al pattern in Arabic) Their

22 In those varieties which distinguish between states, $\mathrm{N}_{2}$ remains in the FS (contrary to genitive constructions).

23 In total, out of the five types described by DixON, type (3) does not appear to be the best represented (only a few eastern varieties have a single form for both attributes and predicates)... unless perhaps one were to consider that the "participial" suffix $-n$ - is the exact equivalent of the genitive preposition $n$ - a hypothesis which is interesting, but needs to be better documented.

24 CHAKER suggests (op. cit.: 30) that Tuareg, a language without adjectives, lost many of the former adjectival class's distinctive features. I believe this to be true of other varieties as well. 
combination in the singular with suffixed person markers in a large number of Berber languages is sufficient to consider that it is an ancient mechanism. The integration of the Perfective of some "quality" verbs (whether stative or not) is probably a secondary development (GALAND 1980) as Zenaga and Awdjili appear to illustrate. The tendency to regularize "intermediate" cases (of which there are others, e.g. numerals and quantifiers, which are not mentioned here) seems to have also affected evaluatives (comparatives and superlatives). One finds traces of an earlier system in some varieties, just as in Kabyle one may consider that the $-n$ ending found on "adjectival" nouns is probably the relic of the "participial" suffix $-n$.

As far as GIVÓN's Time Stability Hypothesis is concerned, one can only note that there is very little semantic specialization of nouns, verbs and adjectives (especially in languages without a specific adjectival class). One does however see specialization within a single class, especially in verbs (cf. Tuareg and its distinction between permanent and transient qualities, or Zenaga and its distinction between stative and processive verbs). Lastly, in some varieties (particularly eastern ones) one observes an interesting specialization whereby "adjectival" nouns are used in the definite and "verbal" adjectives are used in the indefinite.

\section{References}

BASSET, ANDRÉ (1929): La langue berbère. Morphologie. Le verbe. Étude de thèmes. Paris: Leroux. BASSET, ANDRÉ (1952): La langue berbère. London: Dawsons.

Beguinot, FranceSCo (1931): Il Berbero Nefûsi di Fassâto. Roma: Istituto per l'Oriente.

BENTOLILA, FERNAND (1981): Grammaire fonctionnelle d'un parler berbère: Aït Seghrouchen d'Oum Jeniba (Maroc). Paris: SELAF.

BiARnAy, SAMUel (1908): Étude sur le dialecte berbère de Ouargla. Paris: Leroux.

CHAKer, SALEM (1995): Linguistique berbère. Études de syntaxe et de diachronie. Paris/Louvain: Peeters.

CoHen, DAVid \& TAINe-Cheikh, CATHERINe (2000). À propos du zénaga. Vocalisme et morphologie verbale en berbère, in: Bulletin de la Société de Linguistique de Paris XCV, fasc. 1, 269-322.

CREISSELS, DeNIS (2006): Syntaxe générale: une introduction typologique 1: Catégories et constructions. Paris: Hermes Science Publications.

Crookston, Ian (1999): Comparative Constructions, in: Brown, Keith \& Miller, Jim (eds.), Concise Encyclopedia of Grammatical Categories. Oxford: Pergamon, 76-81.

Dixon, Robert M. W. (1999): Adjectives, in: Brown, Keith \& Miller, Jim (eds.), Concise Encyclopedia of Grammatical Categories. Oxford: Pergamon, 1-8.

El Mountassir, ABDallah (1995): Comparer, différencier: l'expression de la comparaison en berbère (tachelhit) du sud-ouest marocain, in: Faits de Langues 5 (La comparaison), 99-107.

FouCAuld, ChARLES DE (1951-52): Dictionnaire touareg-français (Ahaggar). Paris: Imprimerie Nationale de France.

GALAND, LiONEL (1980): Une intégration laborieuse: les "verbes de qualité" du berbère, in: Bulletin de la Société de Linguistique de Paris LXXV, fasc. 1, 347-62.

Galand, Lionel (2002): Types d'expansion nominale en berbère [ $1^{\mathrm{e}}$ éd. 1969], in: Études de linguistique berbère. Leuven/Paris: Peeters, 193-210.

GALAND, Lionel (2006): Le "participe" berbère, in: MetTouchi, Amina \& LonNet, ANTOINE (eds.), Faits de Langues [numéro spécial Les langues chamito-sémitiques (afro-asiatiques) vol. 2] 45-63. Paris: Ophrys.

GALAND, Lionel (2010a): Regards sur le berbère. Milano: Centro Studi Camito-Semitici.

Galand, Lionel (2010b): Deux mille phrases dans un parler berbère du Maroc. Application et évaluation de la méthode d'enquête linguistique d'Henri Frei. Rabat: Institut Royal de la Culture Amazighe (IRCAM). 
Givón, TAlmy (1984): Syntax: a functional typological introduction. Vol. I. Amsterdam: Benjamins.

KOSSMANN, MAARTEN (1997): Grammaire du parler berbère de Figuig (Maroc oriental). Paris/Louvain: Peeters.

KOSSMANN, MAARTEN (2000a): Le futur à Ghadamès et l'origine de la conjugaison verbale en berbère, in: SALEM CHAKER (ed.), Études berbères et chamito-sémitiques. Mélanges offerts à KarlG. Prasse. Paris/Louvain, 237-256.

Kossmann, MAARTEN (2000b): Esquisse grammaticale du rifain oriental. Paris/Louvain: Peeters.

LAFKIOUI, Mena (2007): Atlas linguistique des variétés berbères du Rif. Köln: Rüdiger Köppe.

LANFRY, JACQUES (1968): Ghadamès I. Textes; notes philologiques et ethnographiques. Alger: Fichier de Documentation Berbère.

LANFRY, JACQUES (1973): Ghadamès II. Glossaire. Alger: Le Fichier Périodique.

LaOuSt, ÉmiLE (1931): Siwa. Son parler. Paris: Leroux.

PARADISI, UMBerto (1960): Il berbero di Augila, materiale lessicale, in: Rivista degli Studi Orientali $35,157-177$

PRASSE, KARL-G. (1973-74). Manuel de Grammaire Touarègue (tăhăggart). (1973) VI-VII Verbe. (1974) IV-V Nom. Copenhague: Akademisk Forlag.

Prasse, KARL-G. (1989): Awjili, parler berbère d'Augila, in: Encyclopédie berbère VII. Aix-enProvence: EDISUD, 1052-1054.

Provotelle, Paul (1911): Étude de la Tamazir't ou zenatia de Qalaât Es-Sened (Tunisie). Paris: Leroux.

Souag, Lameen (2010): Grammatical Contact in the Sahara: Arabic, Berber and Songhay in Tabelbala and Siwa, Doctoral thesis. London: SOAS.

TAINE-Cheikh, CATHERINe (1984): Un exemple de créativité lexicale: l'élatif en hassāniyya, in: Arabica 31, fasc. 3, 274-305.

TAINE-CHEIKH, CATHERINE (2003): L'adjectif et la conjugaison suffixale en berbère zénaga, in: Lentin, Jérôme \& Lonnet, Antoine (eds.), Mélanges David Cohen. Paris: Maisonneuve \& Larose, 661-674.

TAINE-CHEIKH, CATHERINE (2008): Dictionnaire zénaga-français. Le berbère de Mauritanie par racines dans une perspective comparative. Köln: Rüdiger Köppe.

TAINE-CheikH, CATHERINE (2009): Â propos de l'expression de l'état en zénaga. Apophonie et souscatégorisation verbale en berbère et en arabe, in: Studi Magrribini (Nuova Serie) VII, 95-109.

TAINE-CheikH, CATHERINE (2012): L'expression du haut degré en zénaga. Étude sémantique et morphosyntaxique, in: IBriszimow, DYMITR; VosSEn, RAINER \& STROOMER, HARRY (eds.), Etudes berbères VI. Essais sur la syntaxe et autres articles. Köln: Rüdiger Köppe, 269-289.

Vogel, Petra M. \& Comrie, Bernard (eds.) (2000): Approaches to the Typology of Word Classes. Berlin: de Gruyter.

VyCICHL, WERNER (2005): Berberstudien \& A Sketch of Siwi Berber (Egypt). Köln: Rüdiger Köppe.

WETZER, HARRIE (1996): The typology of adjectival predication. Berlin: de Gruyter.

CATHERINE TAINE-CHEIKH

LACITO (CNRS - Université Paris III Sorbonne Nouvelle)

7, rue Guy Môquet (bât. D)

94801 Villejuif Cedex (FRANCE)

cath.tainecheikh@gmail.com 